\title{
ПОРІВНЯЛЬНА ОЦІНКА ЯКОСТІ ЖИТТЯ ПІСЛЯОПЕРАЦІЙНИХ ХВОРИХ ІЗ КАЛЬКУЛЬОЗНИМ ХОЛЕЦИСТИТОМ ТА ХОЛЕДОХОЛІТІАЗОМ
}

\author{
${ }^{1}$ Волинська обласна клінічна лікарня Волинської обласної ради, м. Луцьк, Україна \\ ${ }^{2}$ Одеський національний медичний університет, м. Одеса, Україна
}

\begin{abstract}
Мета: визначити показники якості життя у післяопераційних хворих із конкрементами у жовчному міхурі та загальній жовчній протоці. Порівняти хворих, яким виконували лапароскопічну і відкриту операції. Знайти оптимальний шлях лікування.

Матеріали і методи. Для оцінки якості життя використовували опитувальник 36-Item Short-Form Health Status (SF-36). Статистичні дані отримані шляхом ретроспективного аналізу даних, напрацьованих під час лікування хворих в умовах відділення інвазивних методів діагностики та лікування Волинської обласної клінічної лікарні в 2016-2018 рр., а саме: 126 пацієнтів (I група - 52 хворих групи відкритого операційного лікування; II група 74 хворих групи лапароскопічного лікування).

Результати. Після аналізу і підведення статистики було відмічено, що больовий синдром у хворих 3 I групи був наявним лише в перші 2 дні, при чому на другий день після операції відзначався лише при активному русі. У II групі больовий синдром тривав від 4 до 7 днів. В обох групах використовували принципи ERAS (Enhanced Recovery After Surgery). Самостійне вставання хворих у I групі було можливим через $(4,1 \pm 1,9)$ год, у II групі - $(19,7 \pm 3,3)$ год після завершення операції. Пероральне харчування відновили у хворих в I групі через $(14,7 \pm 3,1)$ год, у II групі $(25,9 \pm 5,5)$ год після завершення операції. Дані про самопочуття прооперованих пацієнтів наведені на рисунках 1 і 2 для групи лапароскопічного лікування жовчнокам'яної хвороби і відкритого відповідно.

Висновки. Симультанні лапароскопічні операції з приводу лікування холециститу та холедохолітіазу показують високу есрективність і безпеку. Краще самопочуття, менший больовий синдром і період відновлення сил надають хворому полегшення фрізичне, що гарантує і психологічний комфорт та швидке відновлення загального самопочуття в короткі терміни, і в тривалій перспективі після лапароскопічної холецистектомії та холедохолітотомії.
\end{abstract}

КЛЮЧОВІ СЛОВА: якість життя; калькульозний холецистит; холедохолітіаз; симультанні лапароскопічні операції; післяопераційний період; SF-36.

В останні роки оцінка якості життя набуває більшого значення у світовій медичній практиці як показник загального стану пацієнта, ефективності лікувальних та реабілітаційних заходів, що проводять, а також використовується як прогностичний критерій захворювання [2]. У даній статті подана порівняльна оцінка симультанного лікування жовчнокам'яної хвороби (ЖКХ), а саме відкритої холецистектомії з холедохолітотомією і лапароскопічної холецистектомії з лапароскопічною холедохолітотомією [3, 4, 7].

Методи порівнювали шляхом оцінки післяопераційного періоду в хворих, які перенесли операційне лікування. Післяопераційний період оцінювали через визначення критеріїв якості життя [6, 7].

Ще у 1948 р. ВООЗ визначила здоров'я не лише як відсутність хвороби, але й як наявність фрізичного, психологічного та соціального благополуччя [2]. 3 цього часу в медичній практиці все частіше почали звертати увагу на якість життя [1].

Мета роботи: визначити показники якості життя у післяопераційних хворих із конкрементами у

(․ М. М. Галей, І. П. Марчук, Ю. В. Прокопчук, 2020 жовчному міхурі та загальній жовчній протоці. Порівняти хворих, яким виконували лапароскопічну і відкриту операції. Знайти оптимальний шлях лікування.

Матеріали і методи. Основним інструментом для «кількісного» визначення якості життя $€$ опитувальник [2, 5]. До загальних опитувальників, які найчастіше застосовують для оцінки якості життя, належать Sickness Impact Profile, McMaster Health Index Questionnaire, Nottingham Health Profile, General Health Rating Index, Quality of Life Index, Medical Outcomes Study 36-Item Short-Form Health Status (SF-36), EuroQoL-5D [2]. Крім того, $\epsilon$ ряд спеціальних опитувальників, що прицільно вивчають окремі компоненти якості життя, пов'язаної зі здоров'ям: психологічний статус Psychological General Well Being Index, Profile of Mood State, когнітивну функцію - Digit Span Test, Trail Making Test тощо [2, 5]. У нашій роботі ми користувались опитувальником SF-36, оскільки, на нашу думку, за його допомогою можна швидко і достовірно визначити якість життя і отримати цей показник через числове вираження [6, 7]. Також 
опитувальник є простим для розуміння та інтерпретації для самих хворих, що теж $є$ достатньо важливо для фрормування правдивої статистичної бази. SF-36 складається 336 запитань, що фрормують 8 шкал:

1. Фізичне фрункціонування (Physical Functioning - PF) - відображення ступеня обмеження фрізичного навантаження станом здоров'я (самообслуговування, ходьба, перенесення речей і т. ін.).

2. Рольове фрізичне фрункціонування (RolePhysical Functioning - RPF) - обмеження чи ускладнення фрізичного стану здоров'я виконання повсякденних завдань характерних для особистості (робота, домашні обов'язки і т. ін.).

3. Інтенсивність фрізичного болю (Bodily pain BP) - обмеження звичайних, повсякденних дій.

4. Загальний стан здоров'я (General Health $\mathrm{GH})$ - оцінка хворим свого стану здоров'я на даний момент.

5. Життєві сили (Vitality - VT) - оцінка хворим ресурсів тіла, власної енергії та можливостей.

6. Соціальне функціонування (Social Functioning - SF) - обмеження фрізичного стану здоров'я чи його емоційних наслідків, погіршення соціальних контактів.

7. Рольове емоційне фрункціонування (RoleEmotional - RE) - обмеження чи ускладнення емоційним станом виконання повсякденних завдань характерних для особистості (робота, домашні обов'язки і т. ін.).

8. Психічне здоров'я (Mental Health - MH) характеризує настрій, наявність депресії, тривоги, загальний показник позитивних емоцій.
Чим вищий бал за шкалою опитувальника SF-36, тим кращі показники якості життя. Тестування відбувалось через 1, 3 і 6 місяців за попередньою добровільною згодою. Статистичний аналіз включав дані описової статистики та оцінку достовірності відмінностей. Отримані дані перевіряли, обробляли та аналізували за допомогою комп'ютерної програми.

Для напрацювання статистичної бази ми опрацювали історії хвороб пацієнтів, прооперованих в умовах відділення інвазивних методів діагностики та лікування Волинської обласної клінічної лікарні в 2016-2018 рр., а саме: 126 пацієнтів (I група - 52 хворих групи відкритого операційного лікування; II група - 74 хворих групи лапароскопічного лікування).

Результати дослідження та їх обговорення. Після аналізу і підведення статистики було відмічено, що больовий синдром у хворих 3 । групи був наявним лише в перші 2 дні, при чому на другий день після операції відзначався лише при активному русі. В II групі больовий синдром тривав від 4 до 7 днів. В обох групах використовували принципи ERAS (Enhanced Recovery After Surgery). Самостійне вставання хворих у I групі було можливим через $(4,1 \pm 1,9)$ год, у II групі $(19,7 \pm 3,3)$ год після завершення операції. Пероральне харчування відновили в хворих у I групі через $(14,7 \pm 3,1)$ год, в II групі - $(25,9 \pm 5,5)$ год після завершення операції. Дані про самопочуття прооперованих пацієнтів наведені на рисунках 1 і 2 для групи лапароскопічного лікування ЖКХ і відкритого відповідно.

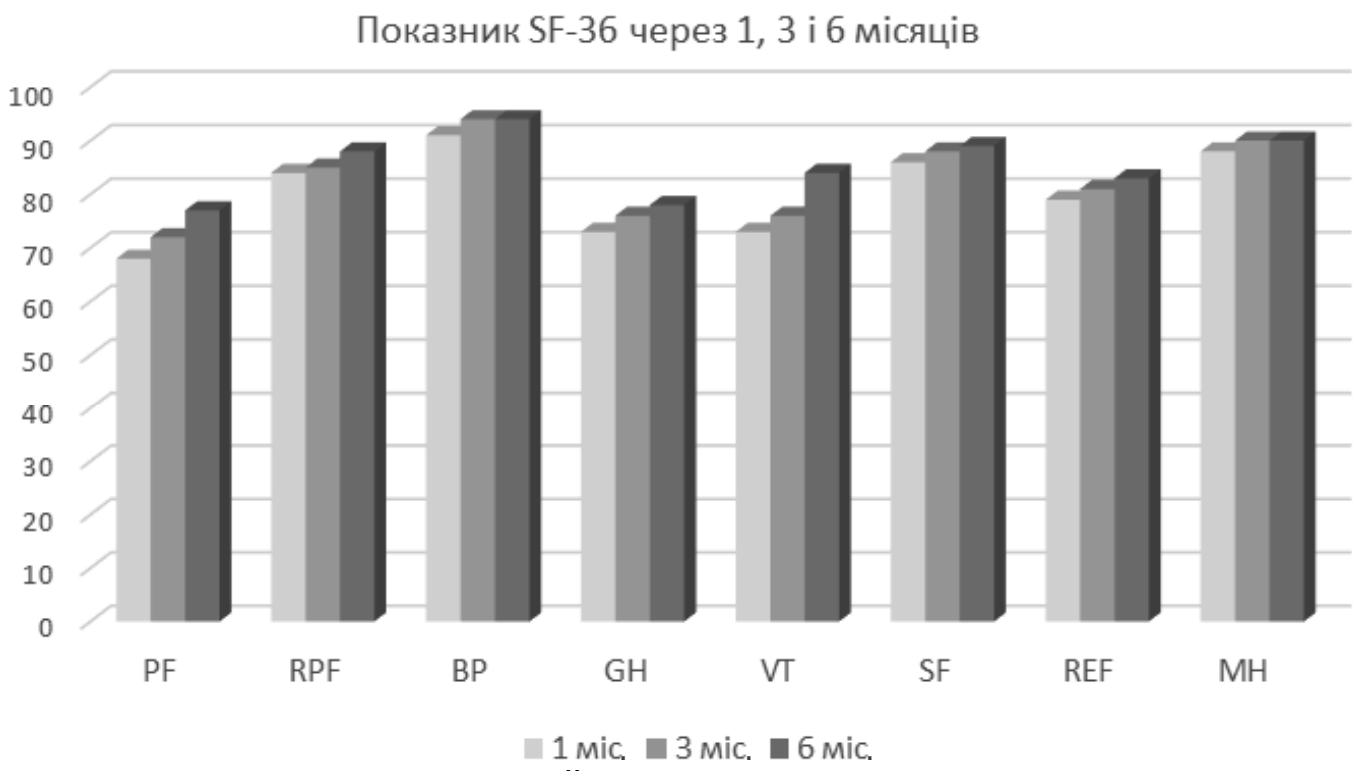

Puc. 1. Оцінка якості життя післяопераційних пацієнтів у групі лапароскопічної холецистектомії та холедохолітотомії.

Можна зрозуміти, що після відкритих операційних втручань реабілітація пацієнтів відбувається повільніше, ніж після лапароскопічних, деколи відновити фрункціональну активність пацієнту не вдається і після піврічної реабілітації. За оцінкою якості життя опитувальником SF-36, дані 


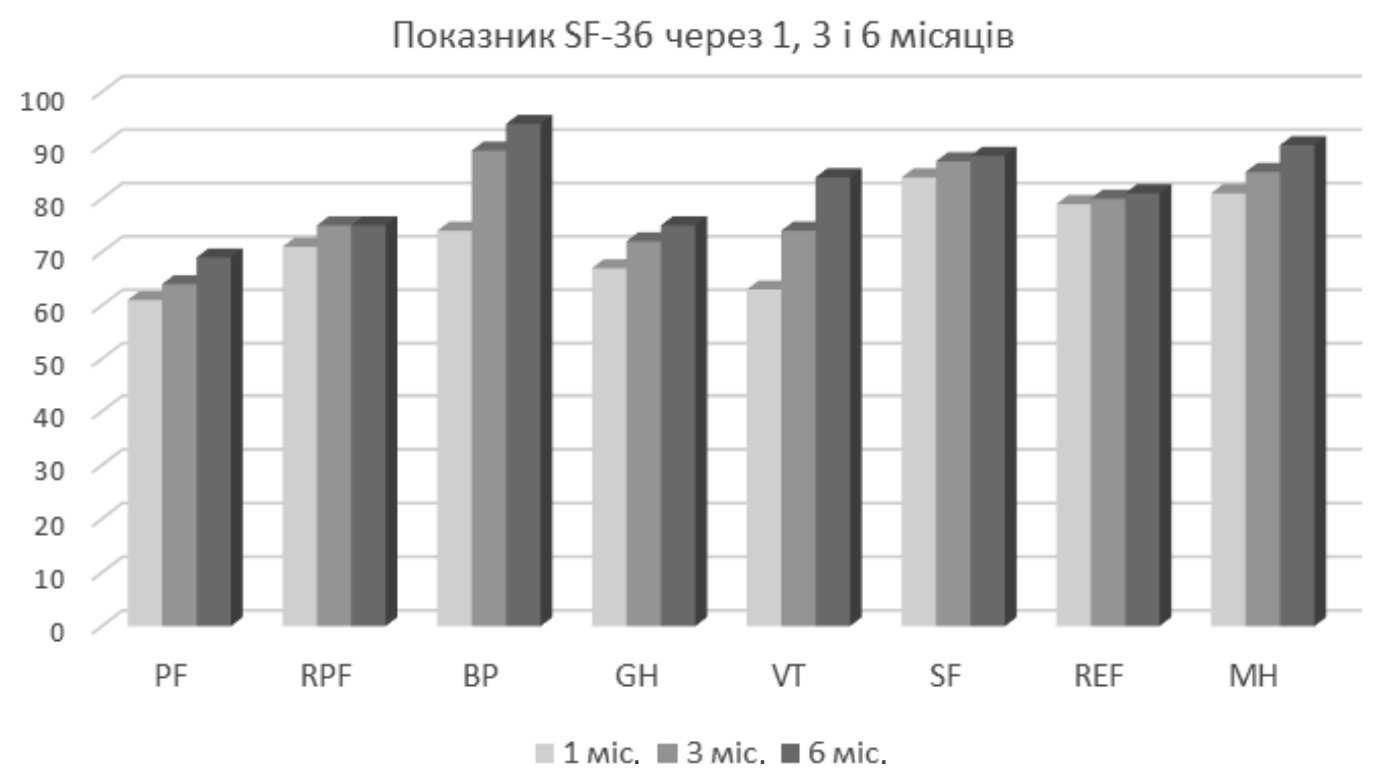

Рuc. 2. Оцінка якості життя післяопераційних пацієнтів у групі відкритої холецистектомії та холедохолітотомії.

вказують не лише на кращі фрізичні показники, а й на повноцінніший стан психологічного здоров'я у хворих, яких лікували малоінвазивно. Це пов'язано $з$ відсутністю вираженого больового синдрому, виснаження після великої операції, косметичного дефекту, психологічно легше сприйняття малих доступів над великим розрізом, а також швидша реабілітація з відновленням фрунцій, що допомагає хворим усвідомити одужання.

\section{Висновки}

1. Симультанні лапароскопічні операції з приводу лікування холециститу та холедохолітіазу показують високу ефективність і безпеку.

2. Лапароскопічні операції хворі краще переносять, вони спричиняють менше болю і диском- фрорту в післяопераційний період, гарантують швидку і коморортну реабілітацію порівняно з відкритими холецистектомією і холедохолітотомією.

3. Краще самопочуття, менший больовий синдром і період відновлення сил надають хворому полегшення фрізичне, що гарантує і психологічний комфорт та швидке відновлення загального самопочуття в короткі терміни, і в тривалій перспективі після лапароскопічної холецистектомії та холедохолітотомії.

Перспективи подальших досліджень пов'язані 3 вивченням рівня якості життя у пацієнтів після симультанних операційних втручань порівняно 3 класичним відкритим методом із приводу інших хірургічних патологій.

\section{Список літератури}

1. Іванько О. В. Порівняльна оцінка якості життя хворих після відкритої та лапароскопічної апендектомії / О. В. Іванько, Р. А. Калина // Шпитальна хірургія. - 2012. - № 3. - С. 26-29.

2. Новик А. А. Руководство по исследованию качества жизни в медицине / А. А. Новик, т. И. Ионова. - М. : Олма медиа групп, 2007. - 320 с.

3. Analysis of post-operative complication in single-port laparoscopic cholecystectomy: A retrospective analysis in 817 cases from a surgeon / Y. Lee, Y. Roh, M. Kim [et al.] // J. Minim. Access Surg. - 2018.

4. Comparison of single-incision laparoscopic cholecystectomy versus needlescopic cholecystectomy: a single institutional randomized clinical trial / A. Umemura, T. Suto, S. Nakamura [et al.] // Dig Surg. - 2018.

5. Robotic cholecystectomy versus conventional laparoscopic cholecystectomy: A meta-analysis / Y. Huang, T. C. Chua, G. J. Maddern, J. S. Samra // Surgery. - 2017. - Vol. 161 (3). - P. 628-636.

6. Safety and feasibility of single-incision laparoscopic cholecystectomy in obese patients / M. Wakasugi, M. Tanemura, M. Tei [et al.] // Ann. Med. Surg. (Lond). - 2016. - Vol. 13. - P. 34-37.

7. Single center experiences of needle-scopic grasper assisted single incision laparoscopic cholecystectomy for gallbladder benign disease: comparison with conventional 3-port laparoscopic cholecystectomy / T. S. Kim, K. H. Kim, C. H. An, J. S. Kim // Ann. Surg. Treat. Res. - 2016. - Vol. 91 (5). - P. 233-238.

\section{References}

1. Ivanko, O.V., \& Kalyna, R.A. (2012). Porivnialna otsinka yakosti zhyttia khvorykh pislia vidkrytoi ta laparoskopichnoi apendektomii [Comparative assessment of the quality of life of patients after open and laparoscopic appendectomy]. Shpytalna khirurhiya - Hospital Surgery, 3, 26-29 [in Ukrainian]. 
2. Novik, A.A., \& Ionova, T.I. (2007). Rukovodstvo po issledovaniyu kachestva zhizni v meditsine [Guidelines for the study of the quality of life in medicine]. Moscow: Olma media grupp [in Russian].

3. Lee, Y., Roh, Y., Kim, M., Kim, Y., Kim, K., Kang, S., \& Jang, E. (2018). Analysis of post-operative complication in single-port laparoscopic cholecystectomy: A retrospective analysis in 817 cases from a surgeon. J. Minim. Access. Surg. DOI:10.4103/jmas.JMAS_168_17.

4. Umemura, A., Suto, T., Nakamura, S., Fujiwara, H., Endo, F., Nitta, H., ..., \& Sasaki, A. (2018). Comparison of singleincision laparoscopic cholecystectomy versus needlescopic cholecystectomy: a single institutional randomized clinical trial. Dig Surg., DOI:10.1159/000486455.

5. Huang, Y., Chua, T.C., Maddern, G.J., \& Samra, J.S. (2017). Robotic cholecystectomy versus conventional laparoscopic cholecystectomy: A meta-analysis. Surg., 161 (3), 628-636. DOI:10.1016/j.surg.2016.08.061.

6. Wakasugi, M., Tanemura, M., Tei, M., Furukawa, K., Suzuki, Y., Masuzawa, T., Kishi, K., \& Akamatsu, H. (2016). Safety and feasibility of single-incision laparoscopic cholecystectomy in obese patients. Ann. Med. Surg. (Lond)., 13, $34-37$. DOI:10.1016/j.amsu.2016.12.048.

7. Kim, T.S., Kim, K.H., An, C.H., \& Kim, J.S. (2016). Single center experiences of needle-scopic grasper assisted single incision laparoscopic cholecystectomy for gallbladder benign disease: comparison with conventional 3-port laparoscopic cholecystectomy. Ann. Surg. Treat. Res., 91 (5), 233-238.

\section{COMPARATIVE ASSESSMENT OF QUALITY OF LIFE IN POSTOPERATIVE PATIENTS WITH CALCULOSIS CHOLECYSTITIS AND CHOLEDOCHOLITHIASIS}

M. M. Halei ${ }^{1}$, I. P. Marchuk ${ }^{1}$, Yu. V. Prokopchuk ${ }^{2}$

${ }^{1}$ Volyn Regional Clinical Hospital of the Volyn Regional Council, Lutsk, Ukraine

${ }^{2}$ Odesa National Medical University, Odesa, Ukraine

Purpoe: to collect and calculate indicators of quality of life in postoperative patients with gallstones of gall bladder and common bile duct. To compare data from patients with open and laparoscopic treatment. To determine optimal way of treatment.

Materials and Methods. For rating quality of life 36-Item Short-Form Health Status (SF-36) was used. The statistic was collected using retrospective analysis of worked out data in laparoscopic surgery unit in Volyn Regional State Hospital where patients underwent surgical treatment (2016-2018). There were 126 patients: 52 patients who underwent conventional surgical treatment (group I) and 74 who underwent laparoscopic treatment (group II).

Results and Discussion. After analysis and summarization of statistics, it was noted that the pain syndrome in patients in group I was present only in the first 2 days, and on the second day after surgery was observed only during active movement. In group II, the pain lasted from 4 to 7 days. ERAS (Enhanced Recovery After Surgery) principles were used in both groups. Independent getting up of patients in group I was possible in (4.1 \pm 1.9$)$ hours, in group II $(19.7 \pm 3.3)$ hours after the operation was completed. Oral nutrition was resumed in patients in group I after $(14.7 \pm 3.1)$ hours, in group II after $(25.9 \pm 5.5)$ hours after the operation was completed. Data on the well-being of operated patients are shown in graphs 1 and 2 for the groups respectively.

Conclusions. Simultaneous laparoscopic operations for the treatment of cholecystitis and choledocholithiasis show high efficacy and safety. Feeling better, less pain and shoter recovery period give the patient physical relief, which guarantees both psychological comfort and rapid recovery of general well-being in the short term and in the long run after laparoscopic cholecystectomy and choledocholithotomy.

KEY WORDS: quality of life; calculous cholecystitis; choledocholithiasis; simultaneous laparoscopic operations; postoperative period; SF-36.

Рукопис надійшов до редакції 21.09.2020 р.

\section{Відомості про авторів:}

Галей Микола Михайлович - кандидат медичних наук, в. о. медичного директора Волинської обласної клінічної лікарні Волинської обласної ради; тел.: +38(050) 378-21-81.

Марчук Іван Петрович - лікар-ординатор відділення інвазивних методів діагностики та лікування Волинської обласної клінічної лікарні Волинської обласної ради; тел.: +38(099) 232-87-21.

Прокопчук Юлія Вікторівна - кандидат медичних наук, доцент кафедри реабілітаційної медицини Одеського національного медичного університету; тел.: +38(067) 484-04-03. 